\title{
Effects of dietary pH and acid source on growth and feed efficiency of the Nile Tilapia, Oreochromis niloticus fry
}

\author{
Ryan V. Fabay 1,3, Barry Leonard M. Tumbokon², Augusto E. \\ Serrano, Jr. ${ }^{1,2 *}$ \\ ${ }^{1}$ Institute of Aquaculture, College of Fisheries and Ocean Sciences, University of the \\ Philippines Visayas, Miagao Iloilo, Philippines \\ ${ }^{2}$ National Institute of Molecular Biology and Biotechnology, University of the Philippines \\ Visayas, Miagao, Iloilo, Philippines \\ ${ }^{3}$ College of Fisheries, Mindanao State University-Maguindanao, Dalican, Datu Odin \\ Sinsuat, Maguindanao, Philippines
}

Key words: dietary $\mathrm{pH}$; organic acids; hydrochloric acid; attractability; feed acidity; Nile tilapia

\begin{abstract}
Two feeding trials were conducted to investigate the effects of dietary $\mathrm{pH}(\mathrm{pH}$ 2.5, 3.7, 4.6, 5.7-control, $\mathrm{pH} 7.0$, and $\mathrm{pH} 8.0$ ) and dietary acid source (acetic acid, citric acid, hydrochloric acid and control-no acid) on growth rate and feed utilization efficiency of the Nile tilapia fry. In addition, attractability of the diets at different $\mathrm{pH}$ and dietary acid sources were determined. Results of the first feeding trial showed that the feed with $\mathrm{pH}$ adjusted to 4.6 resulted in significantly highest final average body weight (FABW), weight gain (WG), specific growth rate (SGR), protein efficiency ratio (PER) and most efficient food conversion ratio (FCR) in the Nile tilapia fry. Survival was $100 \%$ in diets with $\mathrm{pH} 3.7$ up to 7.0 ; the diet with $\mathrm{pH} 2.5$ exhibited significantly lowest survival followed by the $\mathrm{pH} 8.0$ diet. In the second feeding trial, diets that contained hydrochloric, citric or acetic acids that were used to adjust the $\mathrm{pH}$ to the optimal 4.6 resulted in higher FABW, WG, SGR, and PER values but lower FCR values than did the control diet; these parameters were not significantly different among the dietary groups. This study demonstrated that the dietary $\mathrm{pH}$ promoted growth and efficiency in the Nile tilapia fry and that the three acids that were used were similar in their effects on growth and efficiency. Furthermore, it was demonstrated that either acidifying the diet to $\mathrm{pH} 4.6$ by an inorganic acid such as $\mathrm{HCl}$ or the provision of a dietary acidifier such as citric acid or acetic acid could enhance growth, feed efficiency and survival of the Nile tilapia.

* Corresponding author. Email: serrano.gus@gmail.com
\end{abstract}




\section{Introduction}

High inclusion of plant protein in the diet of aquaculture fish serves as an alternative to fish meal in the fish feed industry to achieve aquaculture sustainability and maximized profitability in aquaculture production. Many studies have aimed to optimize the nutritional value of plant protein ingredients by using organic acids or their salts in combination with other additives such as exogenous digestive enzymes to eliminate the antinutritional factors (ANFs) and enhance the nutrients availability by modifying the stomach and intestinal $\mathrm{pH}$ to optimize the activities of the digestive enzymes (Hassaan et al., 2013; Dalsgaard et al., 2012; Hassaan et al., 2019a, Hassaan et al., 2019b). The addition of organic acids or their salts in tilapia diets has been reported to improve feed efficacy (Zhou et al., 2009; Ng et al., 2009; Hassaan et al., 2014; Abu Elala and Ragaa, 2015; Hassaan et al., 2018b). Organic acids or their salts are hypothesized to improve utilization of nutrient in fish based on the assumed mode of action, namely, i) they lower gastric $\mathrm{pH}$ leading to increase digestive enzymes and might increase mineral solubilization during digestion processes; or ii) they modify intestinal microbial activity that might create beneficial nutrient substance (De Wet, 2005; Lückstädt, 2008). To our knowledge, there is only a limited number of studies that have addressed the effect of $\mathrm{pH}$ on the growth of fish except for testing the efficacy of specific acids as feed additive such as malic acid in the Nile tilapia (Chen et al. (2017; Hassaan et al. 2018b), Crucian carp (Carassius auratus, Jing et al., 2013)).

Studies on supplementing an acidifier in the diet of tilapia demonstrated mixed results. Adding potassium diformate (KDF) did not promote growth and feed efficiency in hybrid tilapia Oreochromis niloticus $\times O$. aureus compared with the group with no supplementation at all. $\mathrm{Ng}$ et al. (2009) fed red hybrid tilapia, Oreochromis spp., with various levels of a novel organic acid blend or with $2 \mathrm{~g} \mathrm{~kg}^{-1}$ of KDF. Their data showed that dietary organic acids can exert strong anti-microbial effects and have the potential to exert beneficial effects on growth, nutrient utilization and disease resistance in tilapia. In another study, Hassaan et al. (2014) fed Nile tilapia Oreochromis niloticus with a diet either with no acidifier as control diet, with various levels of calcium propionate or with various levels of calcium lactate. After 90 days of feeding, the fish fed diet containing $1.0 \%$ Ca-lactate recorded the higher protein productive value (PPV) and energy retention (ER) values and apparent digestibility coefficients of crude protein $(C P)$, ether extract (EE), gross energy $(\mathrm{GE})$, Calcium ( $\mathrm{Ca})$, phosphorous $(\mathrm{P})$, potassium $(\mathrm{K})$ and sodium $(\mathrm{Na})$ compared to fish fed the other diets. Soltan et al. (2017) fed groups of Nile tilapia fingerlings with a control diet that did not contain any organic acids nor organic salts, or diets containing various levels of malic acid + oxalic acid blend (OAB) or with diets containing various levels of calcium lactate + sodium acetate blend (OSB). Their results reveal that all fish fed diets containing $1 \%$ of any combination of acid blends were superior to those fed with the control diet in terms of final body weight, weight gain, specific growth rate, feed intake, feed conversion ratio and protein efficiency ratio. In a more recent study of Hassaan et al. (2020), the combination of malic acid and exogenous digestive protease enzymes at various levels of supplementation were evaluated in the Nile tilapia. The results suggest that adding exogenous sources of protease enzymes in combination with malic acid at $5 \mathrm{~g} \mathrm{~kg}^{-1}$ in plant protein-based diet improved growth performance, feed utilization efficiency, digestive enzymes and health status of Nile tilapia. They speculate that the decrease of stomach $\mathrm{pH}$ with the addition of organic acid caused an increase in pepsin activation and mineral absorption, which could be the reason of the improvement of growth and feed efficiency; their observation agrees with the observations of De Wet (2005) and $\mathrm{Ng}$ et al. (2009).They hypothesize that this improvement may be due to an induced optimization of intestinal $\mathrm{pH}$ by malic acid, which in turn helped to pave the exogenous protease activity. El Naby et al. (2019) incorporated sodium butyrate (SB) in a practical diet for Nile tilapia to evaluate its effects on the performance, immunity, and challenge of Nile tilapia against $A$. hydrophilainfection. Their data revealed that dietary SB showed stimulating-effects on fish growth, feed utilization, and innate immunity of Nile tilapia. 
In the present study, our aim was to (1) determine the optimal dietary pH value, using the inorganic hydrochloric acid, that results in the best growth performance, feed utilization efficiency and survival of the Nile tilapia fry (experiment 1) and (2) determine further which among the three acids, one inorganic and two organic acids (hydrochloric, acetic, and citric acids) could enhance the growth parameters of the Nile tilapia fry (experiment 2) at the optimal $\mathrm{pH}$ determined in experiment 1.

\section{Materials and Methods}

The experiments were conducted at the laboratory of the National Institute of Molecular Biology and Biotechnology (NIMBB), University of the Philippines Visayas, Miagao, Iloilo, Philippines.

Experimental tilapia and set up

Two sets of one thousand (1000) sex reversed Nile tilapia (Oreochromis niloticus) fry were procured from the Southeast Asian Fisheries Development Center-Aquaculture Department (SEAFDEC-AQD) in Tigbauan, Iloilo, acclimatized to the basal diet and to the laboratory conditions for 10 days. Four hundred fifty and three hundred tilapia fry were randomly stocked in eighteen and twelve 60L tanks ( 25 fry tank $^{-1}$ ) for the experiments 1 and 2, respectively. The experimental diets were fed to three replicate groups of Nile tilapia fry three times a day. At the start of the experiments and every 15 days, fish were bulkweighed, and satiation feeding was measured at every start day of the week and made as the basis for the feeding rate for the rest of the week; this was made as a routine cycle for the estimation of daily feeding rate until termination on the 56th day. The feeding trial was conducted in a closed recirculating system in which approximately $70 \%$ of the water in the system was replaced every two days. Uneaten feed and feces were siphoned-off each morning before the first feeding. Chlorinated tap water used for replacement (100 ppm $\mathrm{NaClO}$ ) was dechlorinated by letting it stand while being aerated for 3 days. Water quality indices were monitored periodically: temperature and $\mathrm{pH}$ were measured twice a day, dissolved oxygen (DO) twice a week, and nitrite and total ammonia weekly employing commercial water quality kits.

Feed preparation

The basal diet (Table 1) was composed of Peruvian fish meal as the primary protein source in experiment 1 while Danish fishmeal in the second experiment; the rest of the ingredients were squid meal, shrimp meal, soybean meal, rice bran, cornstarch, soybean oil, vitamin premix, trace mineral premix and carboxymethylcellulose (CMC). All of these ingredients were purchased from SEAFDEC-AQD in Tigbauan Iloilo, Philippines and passed through $150 \mu \mathrm{m}$ sieve before use. The composition of the experimental diets is shown in Tables 1 and 2 in experiments 1 and 2, respectively.

Table 1 Composition of experimental diets containing different dietary pH levels fed to the tilapia fry (Oreochromis niloticus) for 56 days.

\begin{tabular}{lc}
\hline Feed Ingredients & Composition (gram) \\
\hline Peruvian fishmeal & 200.0 \\
Squid meal & 130.0 \\
Shrimp meal & 130.0 \\
Soybean meal & 280.0 \\
Rice bran & 120.7 \\
Cornstarch & 50.0 \\
Soybean oil & 30.0 \\
Vitamin premix & 21.7 \\
Trace mineral premix & 21.6 \\
CMC & 16.0 \\
Total & 1000.0 \\
& 49.3 \\
Crude protein & 8.7 \\
Crude fat & \\
Crude fiber & 10.8 \\
Ash & 8.6 \\
Moisture & \\
\hline
\end{tabular}

The Israeli Journal of Aquaculture - Bamidgeh • IJA_72.2020.1114685 
Table 2 Composition of experimental diets with pH adjusted to 4.6 by adding one of the 3 organic acids and fed to the Nile tilapia fry (Oreochromis niloticus) for 56 days.

\begin{tabular}{|c|c|c|c|c|}
\hline \multicolumn{5}{|c|}{ Treatments ( $\%$ composition) } \\
\hline Feed Ingredients & Control & Acetic acid & Citric acid & Hydrochloric acid \\
\hline Danish fishmeal & 180.0 & 180.0 & 180.0 & 180.0 \\
\hline Squid meal & 130.0 & 130.0 & 130.0 & 130.0 \\
\hline Shrimp meal & 130.0 & 130.0 & 130.0 & 130.0 \\
\hline Soybean meal & 280.0 & 280.0 & 280.0 & 280.0 \\
\hline Rice bran & 120.7 & 120.7 & 120.7 & 120.7 \\
\hline Cornstarch & 50.0 & 50.0 & 50.0 & 50.0 \\
\hline Soybean oil & 30.0 & 30.0 & 30.0 & 30.0 \\
\hline Vitamin premix & 21.7 & 21.7 & 21.7 & 21.7 \\
\hline Trace mineral premix & 21.6 & 21.6 & 21.6 & 21.6 \\
\hline CMC & 16.0 & 16.0 & 16.0 & 16.0 \\
\hline Acids & 0.0 & 20.0 & 20.0 & 20.0 \\
\hline Distilled water & 20.0 & 0.0 & 0.0 & 0.0 \\
\hline Total & 1000.0 & 1000.0 & 1000.0 & 1000.0 \\
\hline & \multicolumn{4}{|c|}{ Proximate Composition of the basal diet (\% dry weight basis) } \\
\hline Crude protein & \multicolumn{4}{|c|}{47.7} \\
\hline Crude fat & \multirow{2}{*}{\multicolumn{4}{|c|}{8.1}} \\
\hline Crude fiber & & & & \\
\hline Ash & \multicolumn{4}{|c|}{11.6} \\
\hline Moisture & \multicolumn{4}{|c|}{10.3} \\
\hline
\end{tabular}

\section{Experimental diet and $\mathrm{pH}$ adjustment}

The formulated feeds in experiment 1 was adjusted to $\mathrm{pH} 2.5,3.7,4.6,5.7$ (control), $\mathrm{pH} 7.0$ and $\mathrm{pH}$ 8.0. In experiment 2, the diets were prepared using three different acids, namely, acetic acid, citric acid, and hydrochloric acid to adjust the $\mathrm{pH}$ of the diets to the optimal $\mathrm{pH}$ level for growth and efficiency observed in experiment 1 which was $\mathrm{pH}$ 4.6. The sieved ingredients were manually mixed by shaking them thoroughly inside a big plastic bag. pH adjustment of every diet was done first using a small amount of sample $(10 \mathrm{~g})$ of the mixed powder mixed with distilled water and made up to $30 \mathrm{ml} ; \mathrm{pH}$ was measured and adjusted to the desired $\mathrm{pH}$ by adding either an aqueous $\mathrm{HCl}$ solution or an aqueous $\mathrm{NaOH}$ solution in experiment 1 , or one of the 3 acids in experiment 2 . Following estimation on a small sample, adjustment of $\mathrm{pH}$ was done on a larger scale but final $\mathrm{pH}$ was further measured and adjusted. The resulting dough was pressed flat on an oven tray, cut into noodle-like forms while still a dough and was oven-dried for $12 \mathrm{~h}$ at $80^{\circ} \mathrm{C}$. The dried product was crumbled to appropriate size, stored in plastic containers at $4^{\circ} \mathrm{C}$ until use. The $\mathrm{pH}$ of a sample of the dried diet was again measured in the manner described above for the testing and $\mathrm{pH}$ adjustment of a small sample; this was for final verification.

\section{Attractability test}

Ten runs were conducted using a custom-built rectangular glass tanks with multiple chambers as patterned after Suresh et al. (2011) shown in Figure 1. Six runs were performed in experiment 1 while 4 in experiment 2; each treatment was replicated three times on separate days. Each tank consisted of 3 major chambers (acclimatization chamber, middle chamber, and feeding chamber). The three chambers were separated with removable glass shutters. The feeding chamber consisted of 5 sub-chambers, each with a $6 \times 5 \mathrm{~cm}$ opening so that the juvenile tilapia had access to the feeding chamber.

Each tank was filled with $40 \mathrm{~L}$ freshwater ( 5 parts thousand ${ }^{-1}, \%$ ) and was set up in a laboratory room in which it received only artificial light. Ten tilapia fry $(A B W=0.2 \mathrm{~g})$ were randomly stocked in the acclimatization chamber and allowed to acclimatize for $1 \mathrm{~h}$. Two $\mathrm{g}$ of each test diet were placed in each of the 5 chambers randomly. The shutter was removed $2 \mathrm{~min}$ after feed placement to allow the fish to have access to the feed. Feed 
preference was quantified by counting the number of tilapia fry in the feeding chamber at 1,3 , and 10 min following shutter rising. Percent attractability of each dietary treatment was estimated as the number of tilapia juvenile that entered the feeding chamber of a specific experimental diet divided by the total number of tilapia placed in the acclimatization chamber multiplied by 100 .

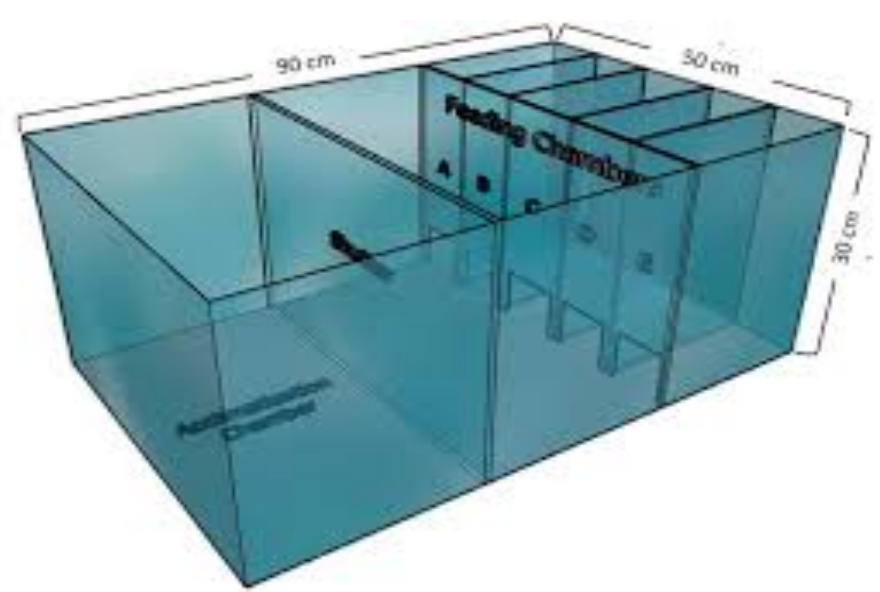

Figure 1 Schematic diagram of the tank used for the attractability test

Growth performance parameters.

Growth performance and feed efficiency were calculated using the following formula: Weight gain (WG), specific growth rate (SGR), feed conversion ratio (FCR), protein efficiency ratio (PER), and survival rate (SR). These parameters were estimated as follows:

$$
\begin{gathered}
\text { WG }(\mathrm{g})=\text { FABW-IABW } \\
\text { FCR }=\text { FI }(\mathrm{g}) / \text { WG }(\mathrm{g}) \\
\text { PER }=(\text { FABW-IABW }) /(\mathrm{FIxFP}) \\
\text { SGR }\left(\% \text { day }^{-1}\right)=100 *(\text { Ln FABW- Ln IABW }) / \mathrm{D} \\
\text { Survival }(\mathrm{SR}, \%)=100 * \text { Final count of fish/Initial count of fish }
\end{gathered}
$$

Where: $F A B W=$ Final average body weight $(g)$ of individual fish; $D=$ days of culture; IABW $=$ initial average body weight $(\mathrm{g})$ of individual fish; FP= Feed protein (in decimal); $F I=$ total feed intake of individual fish for the whole duration of the experiment.

\section{Statistical analysis}

Statistical package for Social Sciences (SPSS) version 20 software was used to perform statistical analysis. Data (survival, weight gain, specific growth rate, and feed conversion ratio) were presented as mean \pm standard error of the mean (SEM). Each set of data were tested for homogeneity of variance and normality of distribution, and upon passing, the data was subjected to one-way analysis of variance (ANOVA) at $\alpha=0.05$. Post hoc analysis was done following ANOVA using Duncan's Multiple Range Test (DMRT) to identify differences between independent factors. The percentage numbers of tilapia fry from attractability test as well as the survival rates were subjected to arcsine transformation, then to the two tests of homogeneity of variance and normality of distribution before subjecting to one-way ANOVA. 
Water quality

\section{Results}

The mean water quality parameters in the whole duration of the experiments were recorded as follows: water temperature range was $21-29^{\circ} \mathrm{C}$; total ammonia nitrogen (TAN) range of $0.1-0.2 \mathrm{mg} \mathrm{L}^{-1}$; average water salinity at $5 \mathrm{~g} \mathrm{~L}^{-1}$, $\mathrm{pH}$ range of 7.5- 8.5 and nitrite range of $0.0-0.2 \mathrm{mg} \mathrm{L}^{-1}$.

\section{Attractability test}

Results showed that the $\mathrm{pH} 4.6$ diet attracted significantly most number of Nile tilapia juvenile than died diets with pH below or above this level (Table $\mathbf{3}$ ). Furthermore, diets containing hydrochloric acid, citric acid and acetic acid which were used to adjust the diet $\mathrm{pH}$ to 4.6 in Experiment 2 resulted in significantly higher attractability rates than did the control diet (Table 4). It was apparent that attractability was more related to the dietary $\mathrm{pH}$ than to the source of the acid.

Table 3 Percent of tilapia fry attracted to the basal and of test diets in Experiment 1 after 10 min of feed placement in the feeding chamber

\begin{tabular}{ll}
\hline Dietary $\mathrm{pH}$ & $\%$ shrimps attracted \\
\hline 2.5 & $8.3 \pm 0.8^{\mathrm{a}}$ \\
3.7 & $13.3 \pm 0.8^{\mathrm{b}}$ \\
4.6 & $28.3 \pm 0.8^{\mathrm{e}}$ \\
5.7 & $18.3 \pm 0.8^{\mathrm{d}}$ \\
7.0 & $16.7 \pm 0.8^{\mathrm{cd}}$ \\
8.0 & $15.0 \pm 0.0^{\mathrm{bc}}$ \\
\hline
\end{tabular}

All values are expressed as mean士SEM. Means in the same column sharing the same subscript are not significantly different $(p>0.05)$.

Table 4 Percent of tilapia fry attracted to the basal and test diets containing various dietary acid sources in Experiment 2 after 3 min of feed placement in the feeding chamber

\begin{tabular}{lc}
\hline Dietary acid source & $\%$ shrimps attracted \\
\hline Acetic acid & $28.3 \pm 1.7^{\mathrm{b}}$ \\
Citric acid & $30.0 \pm 2.9^{\mathrm{b}}$ \\
Hydrochloric acid & $30.0 \pm 0.0^{\mathrm{b}}$ \\
Control-No acid & $11.7 \pm 1.7^{\mathrm{a}}$ \\
\hline All values are expressed as mean $\pm S E M$. Means in the same column sharing the same subscript are not \\
significantly different $(p>0.05)$.
\end{tabular}




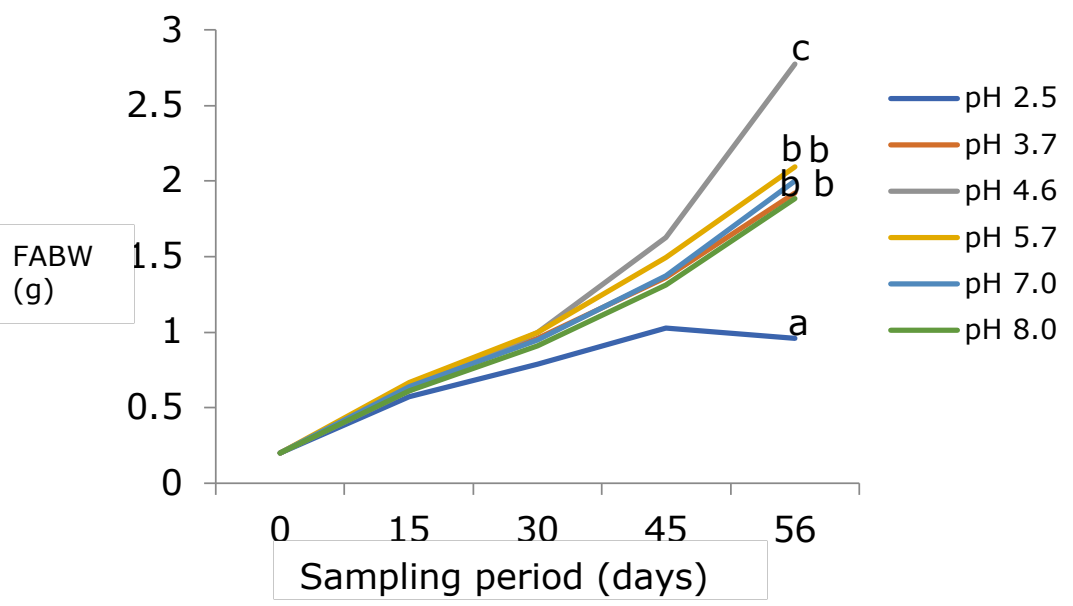

Figure 2 Periodic weight gain of tilapia fry fed the different $\mathrm{pH}$ level of feeds. FIBW= final individual body weight

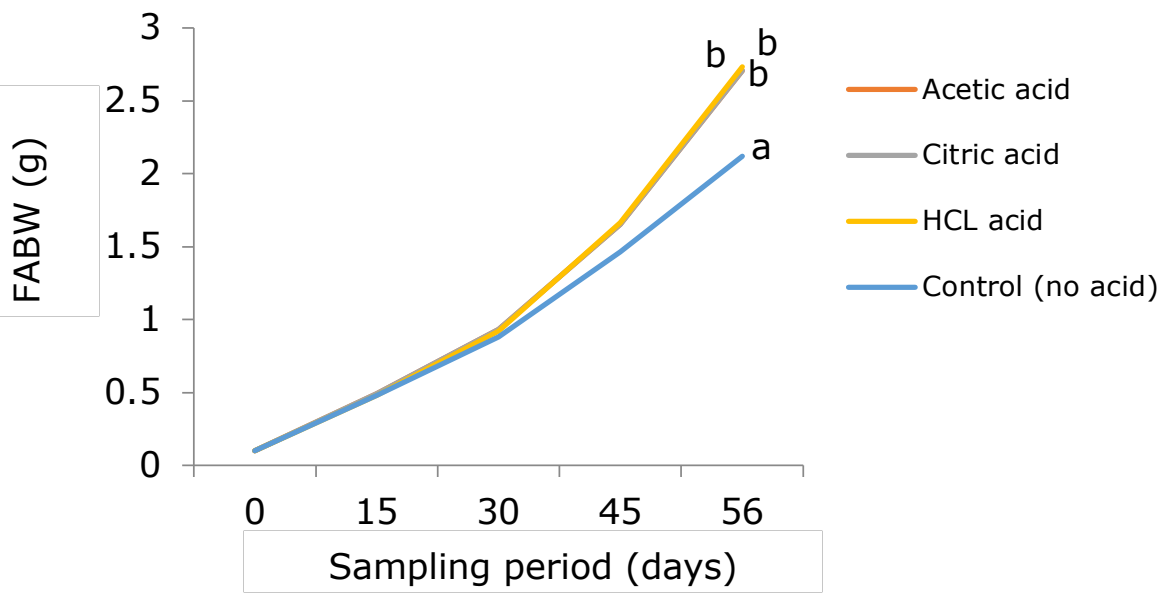

Figure 3 Periodic weight gain of tilapia fry fed to different acid of feeds. FIBW= final individual body weight; $\mathrm{HCL}=$ Hydrochloric

Growth, feed efficiency and survival

Results of the periodic sampling showed that starting at day 30 after stocking and until termination on day 56 the FABW of the Nile tilapia significantly highest in tilapia fed diets whose feed was adjusted to $\mathrm{pH} 4.6$ and higher than those fed the other diets (Figure 2). The FABW of fish fed diets at $\mathrm{pH}$ levels below or above $\mathrm{pH} 4.6$ except that at $\mathrm{pH} 2.5$ were significantly below that of fish fed the $\mathrm{pH}$ diet at $\mathrm{pH} 4.6$ and were not significantly different from each other. Tilapia fed the $\mathrm{pH} 2.5$ diet exhibited significantly the lowest FABW. At the termination of the experiment, tilapia fed the $\mathrm{pH} 4.6$ diet exhibited significantly the highest ABW, WG, and SGR values than those fed diets adjusted to other $\mathrm{pH}$ levels. However, diets at $\mathrm{pH}$ levels $3.7,5.7,7.0$ and 8.0 were not significantly different from each other. The $\mathrm{pH}$ 2.5 diet resulted in the worst growth parameter values. FCR value was lowest in the $\mathrm{pH}$ 4.6 group and the PER value was significantly highest among all treatment groups demonstrating that the diet at $\mathrm{pH} 4.6$ resulted in the conversion of nutrients into flesh (Table 5). Survival rates in fish fed the $\mathrm{pH} 2.5$ and 8.0 diets exhibited a significantly 
lowest survival rates among the other treatment groups. In experiment 2, FABW of diets adjusted to $\mathrm{pH} 4.6$ supplemented with any of the three acids were significantly higher than that of tilapia fed the control diet in which no acid was added and the $\mathrm{pH}$ not adjusted (Figure 3). At the termination of the experiment 2, all tilapia groups fed diets with any organic acid exhibited significantly higher FABW, WG, and SGR values than those fed the control diet. Feed efficiency of the diets with any one organic acid and $\mathrm{pH} 4.6$ were with significantly lower FCR and higher PER values as compared to fish fed the control diet (Table 6). No mortality was observed in all treatment groups in experiment 2.

Table 5 Growth, nutrient utilization efficiency and survival of the Nile tilapia fry after 56 days of feeding diets adjusted to various dietary pH levels

\begin{tabular}{ccccccccc}
\hline pH level & IABW & FABW & FI & WG & SGR & FCR & PER & SR \\
\hline 2.5 & 0.2 & $1.0 \pm 0.1^{\mathrm{a}}$ & $2.7 \pm 0.1$ & $0.8 \pm 0.1^{\mathrm{a}}$ & $1.5 \pm 0.1^{\mathrm{a}}$ & $3.6 \pm 0.3^{\mathrm{c}}$ & $0.3 \pm 0.1^{\mathrm{a}}$ & $86.7 \pm 2.7^{\mathrm{a}}$ \\
3.7 & 0.2 & $1.9 \pm 0.0^{\mathrm{b}}$ & $3.2 \pm 0.1$ & $1.7 \pm 0.0^{\mathrm{bc}}$ & $3.3 \pm 0.1^{\mathrm{bc}}$ & $1.8 \pm 0.0^{\mathrm{b}}$ & $0.8 \pm 0.0^{\mathrm{b}}$ & $100.0 \pm 0.0^{\mathrm{c}}$ \\
4.6 & 0.2 & $2.7 \pm 0.2^{\mathrm{c}}$ & $3.4 \pm 0.2$ & $2.6 \pm 0.2^{\mathrm{d}}$ & $4.9 \pm 0.3^{\mathrm{d}}$ & $1.3 \pm 0.0^{\mathrm{a}}$ & $1.3 \pm 0.0^{\mathrm{c}}$ & $100.0 \pm 0.0^{\mathrm{c}}$ \\
5.7 & 0.2 & $2.1 \pm 0.0^{\mathrm{b}}$ & $3.3 \pm 0.0$ & $1.9 \pm 0.0^{\mathrm{c}}$ & $3.7 \pm 0.1^{\mathrm{c}}$ & $1.8 \pm 0.0^{\mathrm{b}}$ & $0.9 \pm 0.0^{\mathrm{b}}$ & $100.0 \pm 0.0^{\mathrm{c}}$ \\
7.0 & 0.2 & $2.0 \pm 0.1^{\mathrm{b}}$ & $3.2 \pm 0.1$ & $1.8 \pm 0.1^{\mathrm{bc}}$ & $3.5 \pm 0.1^{\mathrm{bc}}$ & $1.8 \pm 0.1^{\mathrm{b}}$ & $0.9 \pm 0.0^{\mathrm{b}}$ & $100.0 \pm 0.0^{\mathrm{c}}$ \\
8.0 & 0.2 & $1.9 \pm 0.1^{\mathrm{b}}$ & $3.1 \pm 0.1$ & $1.6 \pm 0.0^{\mathrm{b}}$ & $3.3 \pm 0.2^{\mathrm{b}}$ & $1.9 \pm 0.0^{\mathrm{b}}$ & $0.8 \pm 0.1^{\mathrm{b}}$ & $92.0 \pm 2.3^{\mathrm{b}}$ \\
\hline
\end{tabular}

Initial average body weight (IABW), average body weight (ABW), weight gain (WG), specific growth rate (SGR), feed conversion ratio (FCR), feed intake (FI), protein efficiency ratio (PER), survival rate (SR). Means in the same column sharing the same superscript are not significantly different $(p>0.05)$.

Table 6 Growth, nutrient utilization efficiency and survival of tilapia fry after 56 days of feeding diets adjusted to $\mathrm{pH} 4.6$ by adding various dietary organic acids.

\begin{tabular}{lcccccccc}
\hline Acids & IABW(g) & ABW(g) & FI $(\mathrm{g})$ & WG $(\mathrm{g})$ & $\begin{array}{c}\text { SGR }(\% \\
\text { day })\end{array}$ & FCR & PER & SR(\%) \\
\hline Acetic & 0.1 & $2.7 \pm 0.1^{\mathrm{b}}$ & $3.8 \pm 0.1$ & $2.6 \pm 0.0^{\mathrm{b}}$ & $4.7 \pm 0.1^{\mathrm{b}}$ & $1.5 \pm 0.3^{\mathrm{a}}$ & $1.5^{\mathrm{b}}$ & $100.0 \pm 0.0$ \\
Citric & 0.1 & $2.7 \pm 0.1^{\mathrm{b}}$ & $3.8 \pm 0.1$ & $2.6 \pm 0.0^{\mathrm{b}}$ & $4.7 \pm 0.1^{\mathrm{b}}$ & $1.5 \pm 0.0^{\mathrm{a}}$ & $1.5^{\mathrm{b}}$ & $100.0 \pm 0.0$ \\
Hydrochloric & 0.1 & $2.7 \pm 0.1^{\mathrm{b}}$ & $3.8 \pm 0.1$ & $2.6 \pm 0.0^{\mathrm{b}}$ & $4.8 \pm 0.2^{\mathrm{b}}$ & $1.4 \pm 0.0^{\mathrm{a}}$ & $1.5^{\mathrm{b}}$ & $100.0 \pm 0.0$ \\
Control & 0.1 & $2.1 \pm 0.1^{\mathrm{a}}$ & $3.5 \pm 0.1$ & $2.0 \pm 0.1^{\mathrm{a}}$ & $3.6 \pm 0.2^{\mathrm{a}}$ & $1.8 \pm 0.1^{\mathrm{b}}$ & $1.2^{\mathrm{a}}$ & $100.0 \pm 0.0$ \\
\hline
\end{tabular}

Initial average body weight (IABW), average body weight (ABW), weight gain (WG), specific growth rate (SGR), feed conversion ratio (FCR), feed intake ( $F I)$, protein efficiency ratio (PER), survival rate $(S R)$. Means in the same column sharing the same superscript are not significantly different $(p>0.05)$.

\section{Discussion}

The global shortage in fish meal supply is pushing feed researchers and manufacturers to use plant protein ingredients in their formulation of feeds. But the challenges that they meet are the presence of antinutritional factors and imbalanced amino acid profiles in plant protein sources. These two factors lead to poor digestibility and growth performance and result in a ceiling limit in their inclusion in aquafeeds. The present study aimed to investigate the effects of varying dietary $\mathrm{pH}$ by using inorganic acid $\mathrm{HCl}$ that could optimize the intestinal $\mathrm{pH}$ of Nile tilapia. The results of the present study showed that the best growth performance and feed utilization was observed in Nile tilapia fed the $\mathrm{pH} 4.6$ diet; using any of the three acids tested, namely, acetic, citric or $\mathrm{HCl}$ to adjust the $\mathrm{pH}$ level to $\mathrm{pH} 4.6$ resulted in similar growth and efficiency performance. The evaluation of growth rates and feed efficiency of the Nile tilapia in relation to dietary $\mathrm{pH}$ in the present study is an indirect comparison of the general physiological conditions in which the total digestive enzyme activities according to their corresponding substrates. The decrease of stomach $\mathrm{pH}$ with the addition of acid in the diet might have caused an increase in pepsin activation and mineral absorption that presumably led to the improvement of growth and feed utilization efficiency (De Wet, 2005; Ng et al., 2009).

The similar improvement on growth performance and feed utilization brought about by acetic, citric and hydrochloric acids demonstrated that it was the dietary $\mathrm{pH}$ and not any 
particular acid was the main factor in the improvement. There are two gastric acidification strategies that have been reported in vertebrates: (1) those that maintain a permanent acidic environment in the stomach which is not affected by the presence or absence of a meal (e.g. mammals and birds), and (2) those that maintain a neutral pH in the lumen of the stomach between meals and becomes slightly acidic after a meal (Papastamatiou and Lowe, 2005). Most teleostean fish that have been studied so far exhibited this second strategy (Hlophe et al., 2014; Nikolopoulou et al., 2011; Yúfera et al., 2004, Yúfera et al., 2012; Solovyev et al., 2016). The first strategy have been observed in cobia juveniles (Yufera et al., 2019), rainbow trout Oncorhynchus mykiss (Bucking and Wood, 2009), southern bluefin tuna Thunnus maccoyii (Leef et al., 2012) and in some elasmobranchian species (Papastamatiou and Lowe, 2005; Papastamatiou et al., 2007); these are strictly carnivorous and the observations were from studies which involved comparison of fed and fasted fish. Erratic daily feeding by changing randomly the moment of feed delivery every day may also alter the daily pattern from neutral/acid alternation to permanent acidification and this has been demonstrated in gilthead seabream Sparus aurata (Montoya et al., 2010). A constant acidic gastric $\mathrm{pH}$ enables this voracious species to be always ready to activate pepsinogen to start the hydrolysis of the ingested prey. In the Nile tilapia in the present study, feeding the fish continually with acidic diets at various $\mathrm{pH}$ levels could have forced a condition of permanent acidification of the lumen (i.e. the first strategy of gastric acidification, Yufera et al., 2019). This implied an environment in which the synthesis of digestive enzymes or activation of already existing digestive enzymes readily occurred for increased nutrient utilization.

In conclusion, the optimal dietary $\mathrm{pH}$ value of adjusted to $\mathrm{pH} 4.6$ diet caused better for growth and feed efficiency in the Nile tilapia under laboratory conditions. Any acids at optimum pH 4.6 diet increased attractability, growth and feed efficiency to Nile tilapia fry.

\section{Acknowledgements}

The authors would like to thank the Philippine Council for Agriculture, Aquatic and Natural Resources Research and Development (PCAARRD) of the Department of Science and Technology (DOST) for the research grant; the Office of the Vice-Chancellor of Research and Extension of the University of the Philippines Visayas for the publication grant, the Faculty Development Program of Mindanao State University-Maguindanao and Accelerated Science and Technology Human Resources Development program-National Science Consortium of Department of Science and Technology (DOST-ASTHRDP) for the Scholarship of Mr. Ryan V. Fabay. We are also grateful to Mr. Vicente Nim, Ms. Apple Gray Deallo, and Ms. Shellah Dee Canillo for their technical support in the laboratory.

\section{References}

Abu Elala, N.M.A., Ragaa, N.M., 2015. Eubiotic effect of a dietary acidifier (potassium diformate) on the health status of cultured Oreochromis niloticus. Journal of Advance Research, 6, 621-629. https://doi.org/10.1016/j.jare.2014.02.008

Bucking, C., Wood, C.M., 2009. The effect of postprandial changes in $\mathrm{pH}$ along the gastrointestinal tract on the distribution of ions between the solid and fluid phases of chyme in rainbow trout. Aquaculture Nutrition, 15(3), 282-296. https://doi.org/10.1111/j.13652095.2008.00593.x

Chen, Y.J., Zhang, T.Y., Luo, L., Shi, Y.Q., Bai, F.J., D.N. Jiang, D.N., 2017. Impact of dietary L-malic acid supplementation on growth, feed utilization, ash deposition, and hepatic lipid metabolism of juvenile genetically improved farmed Tilapia, Oreochromis niloticus. Journal of the World Aquaculture Society, $48(4)$, 563-573. https://doi.org/10.1111/jwas.12388.

Dalsgaard, J., Verlhac, V., Hjermitslev, N., Ekmann, K.S., Fischer, M., Klausen, M., Pedersen, P.B., 2012. Effects of exogenous enzymes on apparent nutrient digestibility in rainbow trout (Oncorhynchus mykiss) fed diets with high inclusion of plant-based protein, Animal Feed Science and Technology, 171 (2-4), 181-191. https://doi.org/10.1016/j.anifeedsci.2011.10.005 
De Wet, L., 2005. May Can organic acid effectively replace antibiotic growth promotants in diets for rainbow trout, Oncorhynchus mykiss raised under suboptimal water temperatures. In WAS Conference, Bali, Indonesia.

El-Naby, A. S. A., Khattaby, A. E. R. A., Samir, F., Awad, S. M., Abdel-Tawwab, M., 2019. Stimulatory effect of dietary butyrate on growth, immune response, and resistance of Nile tilapia, Oreochromis niloticus against Aeromonas hydrophila infection. Animal Feed Science and Technology, 254, 114212. https://doi.org/10.1016/j.anifeedsci.2019.114212

Hassaan, M.S., Wafa, Soltan, M.A., Goda, A.S., Mogheth, N.M.A., 2014. Effect of dietary organic salts on growth, nutrient digestibility, mineral absorption and some biochemical indices of Nile tilapia; Oreochromis niloticus L. fingerlings. World Applied Science Journal, 29 (1), 47-55. 10.5829/idosi.wasj.2014.29.01.81237

Hassaan, M. S., Soltan, M. A., Jarmołowicz, S., Abdo, H.S., 2018. Combined effects of dietary malic acid and $B$ acillus subtilis on growth, gut microbiota and blood parameters of $\mathrm{N}$ ile tilapia (O reochromis niloticus). Aquaculture nutrition, 24(1), 8393. https://doi.org/10.1111/anu.12536

Hassaan, M.S., El Sayed, A.I.M., Soltan, M.A., Iraqi, M.M., Goda, A.M., Davies, S.J., Ramadan, H.A., 2019a. Partial dietary fish meal replacement with cotton seed meal and supplementation with exogenous protease alters growth, feed performance, hematological indices and associated gene expression markers (GH, IGF-I) for Nile tilapia, Oreochromis niloticus. Aquaculture, 503, 282-292. https://doi.org/10.1016/j.aquaculture.2019.01.009 Hassaan, M.S., Mohammady, E.Y., Soaudy, M.R., Abdel Rahman, A.A.S., 2019b. Exogenous xylanase improves growth, protein digestibility and digestive enzymes activities in Nile tilapia, Oreochromis niloticus, fed different ratios of fish meal to sunflower meal. Aquaculture Nutrition, 25(4), 841-853. https://doi.org/10.1111/anu.12903

Hassaan, M. S., Mohammady, E. Y., Adnan, A. M., Elnabi, H. E. A., Ayman, M. F., Magdy, A. M., El-Haroun, E.R. 2020. Effect of dietary protease at different levels of malic acid on growth, digestive enzymes and haemato-immunological responses of Nile tilapia, fed fish meal free diets. Aquaculture, 73512. https://doi.org/10.1016/j.aquaculture.2020.735124

Hlophe, S.N., Moyo, N.A.G., Ncube, I., 2014. Postprandial changes in pH and enzyme activity from the stomach and intestines of Tilapia rendalli (Boulenger, 1897), Oreochromis mossambicus (Peters, 1852) and Clarias gariepinus (Burchell, 1822). Journal of Applied Ichthyology, 30, 35-41. https://doi.org/10.1111/jai.12290

Jing, T., Luo, L., Bai, F., Qian, Q., Sun, Y., Shi, Y., Li, Z., 2013. Effects of L-malic acid on growth performance, body composition, digestion and antioxidant capacity of triploid crucian carp (Carassius auratus). Chinese Journal of Animal Nutrition, 25 (10), 2337-2344. Leef, M. J., Carter, C. G., Nowak, B.F., 2012. Assessment of nutritional status and digestive physiology in southern bluefin tuna Thunnus maccoyii fed a modified baitfish diet. Aquaculture, 350, 162-168. https://doi.org/10.1016/j.aquaculture.2012.03.043

Luckstadt, C, 2008. The use of acidifiers in fish nutrition. Perspectives in Agriculture, Veterinary Science, Nutrition and Natural Resources, 3(044), 1-8. 10.1079/PAVSNNR20083044

Montoya, A., López-Olmeda, J. F., Yúfera, M., Sánchez-Muros, M. J., SánchezVázquez, F.J., 2010. Feeding time synchronises daily rhythms of behaviour and digestive physiology in gilthead seabream (Sparus aurata). Aquaculture, 306(1-4), 315-321. https://doi.org/10.1016/j.aquaculture.2010.06.023

Ng, W. K., Koh, C. B., Sudesh, K., Siti-Zahrah, A., 2009. Effects of dietary organic acids on growth, nutrient digestibility and gut microflora of red hybrid tilapia, Oreochromis sp., and subsequent survival during a challenge test with Streptococcus agalactiae. Aquaculture Research, 40(13), 1490-1500. https://doi.org/10.1111/j.13652109.2009.02249.x

Nikolopoulou, D., Moutou, K. A., Fountoulaki, E., Venou, B., Adamidou, S., Alexis, M.N., 2011. Patterns of gastric evacuation, digesta characteristics and $\mathrm{pH}$ changes along the gastrointestinal tract of gilthead sea bream (Sparus aurata L.) and European sea bass 
(Dicentrarchus labrax L.). Comparative Biochemistry and Physiology Part A: Molecular \& Integrative Physiology, 158(4), 406-414. https://doi.org/10.1016/j.cbpa.2010.11.021

Papastamatiou, Y. P., Lowe, C.G., 2005. Variations in gastric acid secretion during periods of fasting between two species of shark. Comparative Biochemistry and Physiology Part A: Molecular \& Integrative Physiology, 141(2), 210-214. https://doi.org/10.1016/j.cbpb.2005.05.041

Papastamatiou, Y. P., Purkis, S. J., Holland, K.N., 2007. The response of gastric pH and motility to fasting and feeding in free swimming blacktip reef sharks, Carcharhinus melanopterus. Journal of Experimental Marine Biology and Ecology, 345(2), 129-140. https://doi.org/10.1016/j.jembe.2007.02.006

Solovyev, M.M., Kashinskaya, E.N., Rusinek, O.T., Izvekova, G.I., 2016. Physiological $\mathrm{pH}$ values in the digestive tract of perch Perca fluviatilis from different habitats. Journal of Ichthyology, 56 (2), 312-318. 10.1134/S0032945216010148

Soltan, M. A., Hassaan, M. S., Meshrf, R.N., 2017. Response of Nile tilapia (Oreochromis niloticus) to diet acidification: effect on growth performance and feed utilization. Journal of Applied Aquaculture, 29(3-4), 207-219. https://doi.org/10.1080/10454438.2017.1357063

Suresh, A. V., Nates, S., 2011. Attractability and palatability of protein ingredients of aquatic and terrestrial animal origin, and their practical value for blue shrimp, Litopenaeus stylirostris fed diets formulated with high levels of poultry byproduct meal. Aquaculture, 319(1-2),132-140.

https://doi.org/10.1016/j.aquaculture.2011.06.039

Yúfera, M., Fernández-Díaz, C., Vidaurreta, A., Cara, J.B., Moyano, F.J., 2004. Gastrointestinal $\mathrm{pH}$ and development of the acid digestion in larvae and early juveniles of Sparus aurata L. (Pisces: teleostei). Marine Biology, 144, 863-869. 10.1007/s00227003-1255-9

Yúfera, M., Moyano, F. J., Astola, A., Pousao-Ferreira, P., Rodriguez, G.M., 2012. Acidic digestion in a teleost: postprandial and circadian pattern of gastric $\mathrm{pH}$, pepsin activity, and pepsinogen and proton pump mRNAs expression. PLoS One, 7(3): e33687. https://doi.org/10.1371/journal.pone.0033687

Yúfera, M., Nguyen, M. V., Navarro-Guillén, C., Moyano, F. J., Jordal, A. E., Espe, M., Rønnestad, I., 2019. Effect of increased rearing temperature on digestive function in cobia early juvenile. Comparative Biochemistry and Physiology Part A: Molecular \& Integrative Physiology, 230, 71-80. https://doi.org/10.1016/j.cbpa.2019.01.007

Zhou, Z., Liu, Y., He, S., Shi, P., Gao, X., Yao, B., Ringø, E., 2009. Effects of dietary potassium diformate (KDF) on growth performance, feed conversion and intestinal bacterial community of hybrid tilapia (Oreochromis niloticus $\$$ X O. aureus $\sigma^{\prime \prime}$ ). Aquaculture 291, 89-94. https://doi.org/10.1016/j.aquaculture.2009.02.043 